SVU-International Journal of Veterinary Sciences: 1(1): 82-107, 2019.

Print ISSN: 2535-1826

\title{
Change in Behavior, Blood Parameters and Pain Score in Response to Different Treatment Strategies in Bull Infected with FMD or LSD
}

\author{
Ramadan D. EL Shoukary ${ }^{1}$, Nani Nasr eldin ${ }^{2}$ and Ahmed S. Osman ${ }^{3}$ \\ ${ }^{1}$ Department of Animal Hygiene, Faculty of Veterinary medicine, The New Valley University, Egypt \\ ${ }^{2}$ Department of Clinical pathology, Faculty of Veterinary medicine, The New Valley University, Egypt \\ ${ }^{3}$ Department of Biochemistry, Faculty of Veterinary Medicine, Sohag University, Egypt
}

\section{Abstract}

Foot and mouth disease and lumpy skin disease of cattle is a common disease on commercial cattle farms which associated with changes in behavior, blood parameters, pain related behaviors and pain scale measurements, but little is known about this effect. The objectives of the present study were to test 2 hypotheses. First, investigate these changes; second, explained the effect of different treatment strategies (analgesic with Flunixin meglumine) or non-analgesic on lameness and pain scale. 125 bull cows were enrolled in the study based on visual observation of abnormal behavior the present study was done in Assiut governorate in Egypt was divided in three groups, which 25 clinically healthy bull (control group), FMD clinically infected group (25 analgesic +25 non-analgesic and LSD (25 analgesic +25 non analgesic). Obtained data illustrated that; there are significant increase physiological parameters (rectal temperature, heart rate and respiratory rate), lying behavior and total pain scale, while, there are significant decrease in feeding, drinking, rumination and standing behaviors, activity of exploration and activity of body care which may be corrected by Flunixin using.

Conclusion: Flunixin injection may help in decreasing the negative pain behaviors and physiological changes caused by LSD or FMD

Keywords: Flunixin, pain behavior, pain scale and pain management.

DOI: $10.21608 / \mathrm{svu} .2019 .6807 .1004$

Received: December 22, $2018 \quad$ Accepted: March 15, $2019 \quad$ Published: March 20, 2019

*Corresponding Author: Ramadan D. EL Shoukary E-mail: ramadandardeer8@gmail.com

Citation: Change in Behavior, Blood Parameters and Pain Score in Response to Different Treatment Strategies in Bull Infected with FMD or LSD. SVU-IJVS, 2 (1): 82-107.

Copyright: (C) EL Shoukary et al., This is an open access article distributed under the terms of the creative common attribution license, which permits unrestricted use, distribution and reproduction in any medium provided the original author and source are created.

Competing interest: The authors have declared that no competing interest exists. 


\section{Introduction}

Monitoring sickness behavior may improve identification, management, and welfare of sick animals and behavioral changes may be useful indicators of early stages of disease. (Hixson et al., 2018). Sickness and pain can lead to some behavioral changes (Lomb et al.,2017) as, diseased animals decreased its activity in exploration and body care as well as poor appetite which done as an adaptive response by it to enhance disease resistance and facilitate recovery from disease (Johnson, 2002). Besides that, changes in the frequency of maintenance behaviors such as standing, eating, and drinking specific postures. (Weary et al., 2006; Rushen et al., 2008 and Millman, 2013); reduced feeding, and increased resting (Dantzer and Kelley, 2007) this changes as result from homeostasis and physiological changes which associated with pain include heart rate (Stewart et al., 2010), rectal temperature and respiratory rate (Heinrich et al., 2009) accompanied with changes in facial expression providing a valuable clues about an animal's pain experience (Brown et al., 2013). For example, compared with healthy cows, ill cows spend less time feeding (Gonzalez et al.,2008;); alter its lying behavior in response to sickness (Sepulveda-Varas et al., 2014) and pain (Molgaard et al., 2012); which act as an indicator used to assess changes in cattle welfare particularly for comfort, pain and disease evaluation such lameness (Mattachini et al., 2011).

Foot and mouth disease are a viral disease of domestic cloven-hoofed animals causing a huge economic loss (Kandeil et al., 2013) characterized by fever, anorexia, salivation, vesicle, vesicular eruptions and formation of erosions and ulcers (Kitching et al., 2005). These vesicles may locate on the tongue, hard palate, dental pad, lips, gums, muzzle and interdigital spaces (Kitching,2002). Pain resulting from vesicles and vesicular eruptions on the feet results in lameness, tucked up stance and reluctance to stand or walk and animals may also be depressed and inappetant (Alexanderson, 2003) or on tongue causing abundant secretion of foamy saliva (Kitching, 2002) Consequently, feeding, milking and suckling become difficult, resulting in a rapid weight loss and a marked decrease in milk production (Shahan, 1962). On the other side, Lumpy skin diseased (LSD) is a viral disease of cattle characterized by fever, nodules on the skin, edema of the skin, enlargement of superficial lymph nodes sometimes swelling in forelimbs causing some lameness (Tulman et al., 2001). Despite this overall agreement on painful conditions in cattle, still, too few veterinarians give proper pain-relieving treatments and farmers are even more reluctant to use analgesics (Thomsen et al., 2012). The reasons for this restricted use of analgesics may be economic reasons, practical reasons, habits and lack of knowledge. As cattle are production animals, drug regulations are very restricted and complicated, which also influences the choice of treatment. To alleviation of pain and inflammation; support the cow's wellbeing; reduce the period of depression and loss of appetite this may be achieved by a non-steroidal anti-inflammatory drugs (NSAIDs) NSAIDs using which may be due to their antipyretic and anti-inflammatory effects, which reduce the clinical signs and inflammatory parameters that accompany diseases (Giammarco et al.,2016). Flunixin meglumine one from this family which licensed for use in food animals which approved for intravenous (i.v.) administration to beef and dairy cattle for 
control of pyrexia, and inflammation (Teresa et al., 2014) it is administered at a dose of $1.1 \mathrm{mg} / \mathrm{kg}$ (Mcilwraith et al., 2001). It used as extra-label therapy for pain relief in cattle (Fajt et al., 2011) and reduce disease process in cattle (Lockwood et al., 2003) the full analgesic and antipyretic effects usually occur 1-2 hours following treatment, but there is often an effective analgesic effect within approximately 15 minutes despite its short plasma half-life of 1.6-2.5 hours, effects can persist for up to 30 hours (May, 1996) with maximal effects occurring between 2 and 16 hours. This is likely due to an accumulation of the drug at inflammatory foci it has a 4-day withdrawal time based on the hepatic depletion of the marker residue. (USFDA, 2004).

To detect the pain occurred in farm animals due to FMD and LSD viral infection can be done by using the pain scoring scale which a fast and easy useful technique used by both veterinarians and farmers in a practice (Karina, 2017) besides that, using the previously described physiological and behavioral changes indicators. To our knowledge, no research has investigated if cows alter their behavioral, physiological and pain scale indicators in response to the pain of FMD or LSD viral infection. Thus, the aim of our study was to investigate this changes and role of Flunixin or different treatment strategies in alleviation this pain.

\section{Materials and Methods}

\section{Animals and studying area}

The study was carried out in Assiut governorate which is one of the Upper Egypt governorates. A total of 125 bull cattle (aged from 2-4 years) during the period from September 2017 to February 2018 were used in the present study. Data collecting from 20 small holder animal farms each which site at same surrounding area (about 5 Kilo meter around) in BaniAdi Village, Manfalut Center, Assiut governorate, Egypt. Each holder has 4:30 bull animals reared in a room size ranged from 15:60 m2 which animals stay at night and yard which maintain in morning (6 am: $5 \mathrm{pm}$ ). LSD Affected animals' numbers in each farm was ranged from 2:6 while, FMD affected animals ranged from 4:30 animals which divided by its colour in small numbers or nontoxic spray on its back and buttocks (red colour nonanalgesic and blue was analgesic) in large one each farm act as replicate. It was 6 farms (replicate) in case of FMD and another 14 farm (replicate) in case of LSD. All environmental condition was nearly same because it is occurred in same area. The control group data was collected from the previously mentioned farm from clinically healthy animals.

These animals were divided according to clinical examination in to:

1. Control group which clinically healthy singes ( 25 animals).

2. Foot and Mouth disease (FMD) cattle (25 analgesics +25 non-analgesic animals).

3. Lumpy skin diseased (LSD) cattle (25 analgesic+ 25 non-analgesic animals)

\section{Feeding and watering}

Feed and water were offered in front of the animals three times per day at $8 \mathrm{Am}, 11$ $\mathrm{pm}$ and $4 \mathrm{pm}$ and the animal was free to move.

\section{Pain treatment strategies}

1) Lumpy skin infected animals divided in two types:

a) Non-analgesic group (treated with Terramycin ${ }^{\circledR}$ long-acting (oxytetracycline) 
$1 \mathrm{ml} / 10 \mathrm{~kg}$ body weight IM one every 3 days, $10 \mathrm{ml}$ of levamizole ${ }^{\circledR}$ (levamisole) per animal was also injected subcutaneously as immune enhancer was modified of Salib and Osman (2011).

b) Analgesic group (treated as nonanalgesic + Flunixin ${ }^{\circledR}(2 \mathrm{ml} \backslash 45 \mathrm{~kg}$ of animals each day for 5 successive days from observation of the clinical signs at 7 Am. before feeding or drinking this treatment only in an analgesic group.)

2) Food and mouth diseased animals divided into two types:

a) Non analgesic group (treated with oral lesions were sprayed twice daily by Phenytoin (Healosol®) after washed with physiological saline solution to remove necrotic tissues (Al-Lethie et al., 2016) with systemically intramuscular injection of antibiotic (Pan \&Strep ${ }^{\circledR} 1 \mathrm{ml} / 25 \mathrm{Kg}$ of animal daily for 5 days due to Viremia appears as soon as $24 \mathrm{~h}$ post-exposure and lasts 4-5 days in ruminants (Stenfeldt et al., 2016) to facing the secondary bacterial infection

b) Analgesic group (treated as nonanalgesic + Flunixin ${ }^{\circledR}(2 \mathrm{ml} \backslash 45 \mathrm{~kg}$ of animals each day for 5 successive days from observation of the clinical signs at 7 Am. before feeding or drinking this treatment only in analgesic group) Despite Flunixin meglumine's observed elimination half-life of less than $5 \mathrm{~h}$ in cattle with inflammatory conditions, we detected the effects of a single IV dose until the end of the $24 \mathrm{~h}$ post-treatment observation period. (Wagner et al., 2016)

\section{Measured parameters}

1) Physiological parameters according to (Radostits et al., 2007)

Heart rate (HR), rectal temperature (RT) and respiratory rate (RR) were examined and it's measured twice daily at $8 \mathrm{Am}$ and $4 \mathrm{pm}$ (before feeding or drinking) to has the average.

2) Appetite score according to (Duz et al., 2012)

Appetite score (APP) ranged from 1 to 4 (No appetite $=1$, little appetite $=2$, good appetite $=3$ and very good appetite $=4$ ) it done at 3 PM daily. (Flunixin maximum level in blood)

\section{Behavioral observations}

Behavior was recorded by using the instantaneous scanning sampling technique described by (Altman, 1974 and StampDawkins, 2007). Behavior of each group was recorded for 20 minutes for three times daily for the three consecutive days of experiment as (at morning from 8:00 to 9:00 AM, midday from 11-12 pm and at afternoon from 16:00 to 17:00 PM these day periods were chosen depending on the daily schedule of concentrate feeding) to give 1-hour daily observation of predefined behavioral item as table (I). Data were presented as the percentage of a certain activity to the total activities recorded.

\section{The cow pain scale}

The cow pain scale consists of 7 behaviors, evaluated from 0-2 and combined into a total pain score as explained in a table (II). 
Table 1: Behavioral Ethogram

\begin{tabular}{|l|l|}
\hline \multicolumn{1}{|c|}{ Behavior } & \multicolumn{1}{c|}{ Description } \\
\hline 1) Maintenance & \\
behaviors A) Bull & Bull is standing on four legs \\
posture & Abdomen of cow touches the floor \\
1) Standing behavior & Standing and moving on all 4 legs \\
2) Lying behavior & Bull muzzle in concentrate or roughages show ingesting and \\
3) Walking & chewing movements. Bull show masticating, regurgitating, \\
B) Ingestive behavior & chewing, and swallowing. \\
1) Eating behavior & Bull muzzle in water bowel and consume water. \\
2) Ruminating behavior & \\
3) Drinking behavior & Cow movement and contact with other material or things in \\
2) Sickness behavior & rearing area. \\
a) Activity in exploration \\
b) Activity in body care
\end{tabular}

Table 2: Pain scales

\begin{tabular}{|l|l|l|l|}
\hline \multicolumn{1}{|c|}{ Behaviors } & \multicolumn{1}{|c|}{ zero } & \multicolumn{1}{c|}{$\mathbf{1}$} & \multicolumn{1}{c|}{$\mathbf{2}$} \\
\hline $\begin{array}{l}\text { Active towards } \\
\text { outside }\end{array}$ & $\begin{array}{l}\text { Active in eating, } \\
\text { ruminating, grooming }\end{array}$ & $\begin{array}{l}\text { Not attentive, } \\
\text { quiet/depressed } \\
\text { avoiding eye contact, } \\
\text { or observer }\end{array}$ & Head very low \\
\hline Head position & $\begin{array}{l}\text { Head held high level of } \\
\text { withers }\end{array}$ & $\begin{array}{l}\text { Head lower than } \\
\text { withers }\end{array}$ & Lamb's or low ears \\
\hline Attention & $\begin{array}{l}\text { Both ears forward or Active } \\
\text { movable }\end{array}$ & $\begin{array}{l}\text { Both ears back } \\
\text { Attentive/neutral look, } \\
\text { focused on } \\
\text { (eating, ruminating) a task }\end{array}$ & $\begin{array}{l}\text { Tense } \\
\text { expression/strained } \\
\text { appearance; worried } \\
\text { or strained look } \\
\text { furrows above the eyes } \\
\text { and puckers above the } \\
\text { nostrils }\end{array}$ \\
\hline
\end{tabular}




\begin{tabular}{|l|l|l|l|}
\hline Response to & $\begin{array}{l}\text { Look at observer, head up, } \\
\text { ears forward or occupied } \\
\text { with activity (grooming, } \\
\text { ruminating), not scared and } \\
\text { remain lying down with a } \\
\text { high head and ears forward } \\
\text { until the person approaching } \\
\text { is getting near, then she will } \\
\text { get up and walk off in a } \\
\text { hurry. }\end{array}$ & $\begin{array}{l}\text { Look at observer, ears } \\
\text { not } \\
\text { forward, leave when } \\
\text { approached }\end{array}$ & $\begin{array}{l}\text { May/may not look at } \\
\text { observer, head low, } \\
\text { ears not } \\
\text { Forward and may } \\
\text { leave slowly, Not } \\
\text { interested, scared, not } \\
\text { so motivated to get up, } \\
\text { especially if the pain } \\
\text { in legs or claws. }\end{array}$ \\
\hline Back position & $\begin{array}{l}\text { Straight line } \\
\text { Not lame } \\
\text { Normal and rhythmic } \\
\text { strides }\end{array}$ & $\begin{array}{l}\text { Shorter and non- } \\
\text { rhythmic strides }\end{array}$ & $\begin{array}{l}\text { Arched back } \\
\text { Very lame } \\
\text { No support on one leg } \\
\text { or very } \\
\text { unequal and short } \\
\text { strides }\end{array}$ \\
\hline
\end{tabular}

The first 4 behaviors are evaluated from a distance, while the cow is not yet alerted to the person observing. Then the cow is approached and the response to approach is evaluated. When the cow is standing up, the back position may be evaluated, and finally, the lameness is evaluated. Once accustomed to the scale, this does not take more than about a minute. The pain scoring is obviously not intended routinely for all animals; rather, it is a tool for evaluating the cows that are noticed to look different than normal during the daily round through the barn. This pain score is guiding, but if the pain score is above 5, the cow could be in pain and should be observed and re-evaluated or examined by the veterinarian. (Karina, 2017). It was done at 3 PM daily. (Flunixin maximum level in blood)

\section{Blood analysis}

10 Blood samples of each group were collected aseptically from the jugular vein of (control, analgesic LSD, non-analgesic LSD, analgesic FMD and non-analgesic FMD) with or without EDTA.

1) Haematological parameters
Red blood cells (RBCs) and white blood cells (WBCs) count in blood collected at $10 \%$ EDTA was determine by an automatic cell counter (Feldman et al. 2000)

\section{2) Biochemical parameters}

Total serum protein, albumin, glucose, calcium, and phosphorus were estimated using commercially available kits. While Serum globulin concentration was calculated by subtracting the measured albumin level from the total protein level (Doumas andBiggs 1972). Oxidative stress markers as Glutathione (GSH) and lipid peroxidation (MDA) in the serum were determined via the approaches used by Owens and Belcher (1965) and Ohkhawa et al. (1979), respectively.

\section{Statistical analysis}

For the analysis, a pen or a farm was considered as the experimental unit. The data were analyzed by one-way ANOVA procedure using the statistical computer Program SPSS 16 Software (SPSS Inc., Chicago, IL, USA) to compare between means, significance was designated as $\mathrm{P}<$ 0.05 . Means were compared to Duncan's 
test when a significant difference was detected.

\section{Results}

Table (3 \& 4) showed that, there are significant increases in heart rate, rectal temperature, respiratory rate and cow pain scale while, there is a significant decrease in appetite score was found between controls and treated and none treated groups. Besides that, there are significant increases in lying behavior while, a significant decrease in feeding, drinking, rumination, standing, exploration and body care behavior was found between control and treated and none treated groups this data illustrated in figure (1-8). On the other hand, data found in table (5) illustrated that, in comparing to control one, FMD Analgesic group there was significant increase in (Globulin and Inorganic phosphorus) while, significant decrease in (RBC, WBS, total proteins, albumin and $\mathrm{A} / \mathrm{G}$ ratio) Moreover, LSD Analgesic group has significant increase in (RBC, Globulin, and Inorganic phosphorus) and significant decrease in (WBS, total protein, albumin, albumin, and $\mathrm{A} / \mathrm{G}$ ratio)

Table 3: Physiological and appetite score of animals infected with FMD and LSD virus (analgesic or non-analgesic

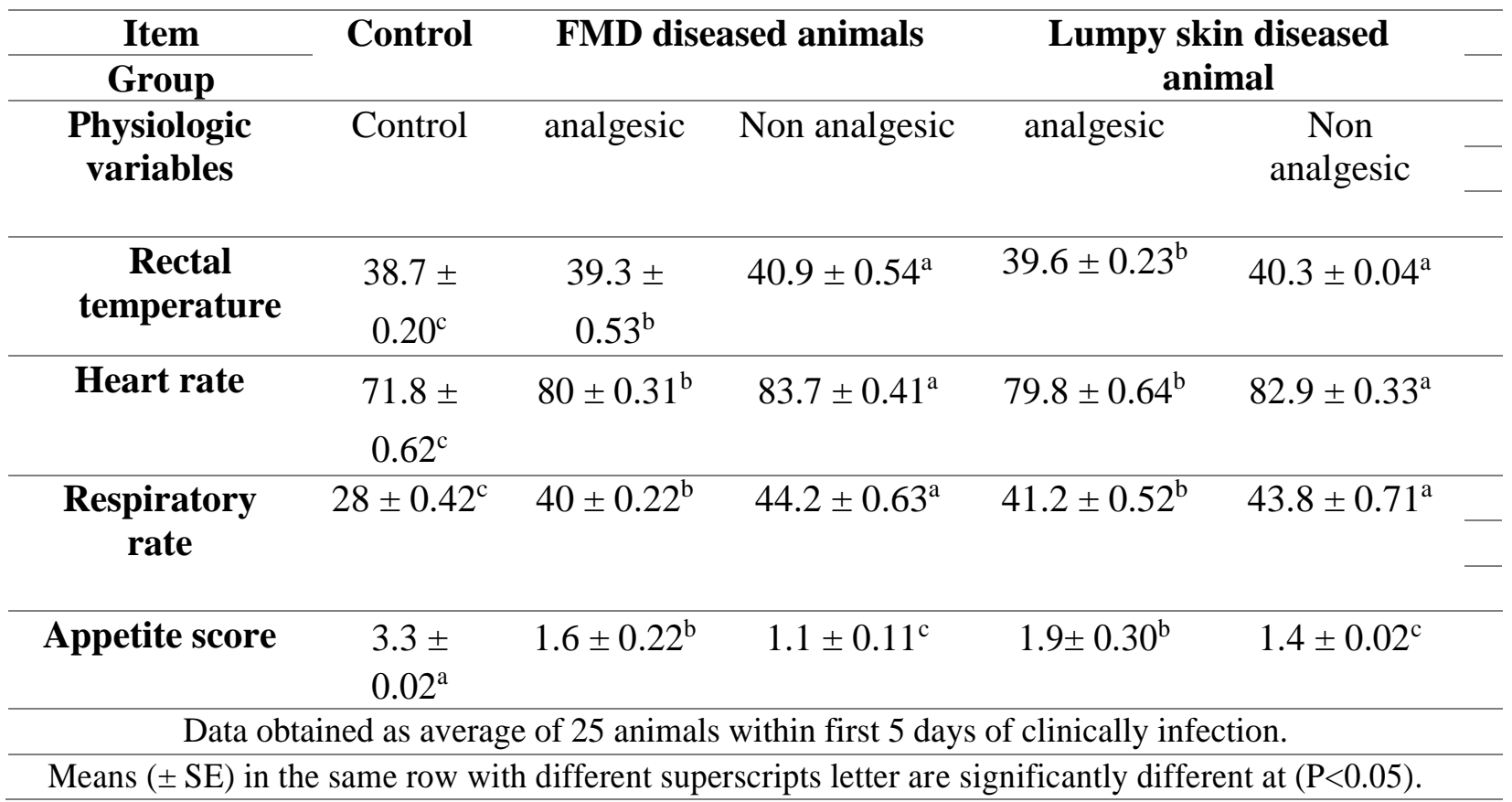


Table 4: Pain scale parameters of animals infected with FMD and LSD virus (analgesic or non-analgesic)

\begin{tabular}{|c|c|c|c|c|c|}
\hline \multirow[b]{2}{*}{$\begin{array}{l}\text { Pain scale } \\
\text { parameter }\end{array}$} & \multirow[b]{2}{*}{ Control } & \multicolumn{2}{|c|}{ FMD diseased animals } & \multicolumn{2}{|c|}{$\begin{array}{c}\text { Lumpy skin diseased } \\
\text { animal }\end{array}$} \\
\hline & & analgesic & $\begin{array}{c}\text { Non } \\
\text { analgesic }\end{array}$ & analgesic & $\begin{array}{c}\text { Non } \\
\text { analgesic }\end{array}$ \\
\hline Attention & 0 & 0.21 & 0.41 & 0.21 & 0.40 \\
\hline Head position & 0 & 1.10 & 1.62 & 1.12 & 1.31 \\
\hline Ear position & 0 & 1.22 & 1.32 & 1.11 & 1.00 \\
\hline Facial expression & 0 & 0.83 & 1.00 & 0.91 & 1.00 \\
\hline $\begin{array}{l}\text { Response to } \\
\text { approach }\end{array}$ & 0 & 0.90 & 1.20 & 0.80 & 1.00 \\
\hline Back position & 0 & 1.41 & 1.70 & 0.90 & 1.00 \\
\hline Lameness & 0 & 1.80 & 2.1 & 0.62 & 0.72 \\
\hline Total pain score & $0^{d}$ & $7.41^{b}$ & $9.21^{\mathrm{a}}$ & $5.61^{\mathrm{c}}$ & $6.41^{b}$ \\
\hline
\end{tabular}


Table 5: Blood parameters of animals infected with FMD and LSD virus (analgesic or nonanalgesic)

\begin{tabular}{|c|c|c|c|c|c|}
\hline \multirow[b]{2}{*}{ Items } & \multirow{2}{*}{$\begin{array}{c}\text { Control } \\
\begin{array}{c}\text { Apparently } \\
\text { healthy }\end{array}\end{array}$} & \multicolumn{2}{|c|}{$\begin{array}{l}\text { FMD diseased } \\
\text { animals }\end{array}$} & \multicolumn{2}{|c|}{$\begin{array}{l}\text { Lumpy skin diseased } \\
\text { animals }\end{array}$} \\
\hline & & Analgesic & $\begin{array}{c}\text { Non } \\
\text { analgesic }\end{array}$ & Analgesic & $\begin{array}{c}\text { Non } \\
\text { analgesic }\end{array}$ \\
\hline \multicolumn{6}{|c|}{ Hematological parameters } \\
\hline $\mathrm{RBC} \times 10^{6} / \mu \mathrm{l}$ & $5.61 \pm 0.31^{\mathrm{b}}$ & $4.72 \pm 0.12^{\mathrm{c}}$ & $4.62 \pm 0.40^{c}$ & $6.80 \pm 0.62^{\mathrm{a}}$ & $6.62 \pm 0.11^{\mathrm{a}}$ \\
\hline $\mathrm{WBC} \times 10^{3} / \mu \mathrm{l}$ & $6.40 \pm 0.02^{\mathrm{a}}$ & $5.51 \pm 0.01^{\mathrm{b}}$ & $6.02 \pm 0.08^{\mathrm{a}}$ & $4.33 \pm 0.8^{\mathrm{b}}$ & $4.91 \pm 0.92^{\mathrm{b}}$ \\
\hline \multicolumn{6}{|c|}{ Biochemical parameters } \\
\hline Total Protein (g/dl) & $6.61 \pm 0.61^{\mathrm{a}}$ & $5.80 \pm 0.70^{b}$ & $5.42 \pm 0.72^{c}$ & $5.91 \pm 0.72^{\mathrm{b}}$ & $5.70 \pm 0.73^{b}$ \\
\hline Albumin (g/dl) & $3.82 \pm 0.23^{\mathrm{a}}$ & $2.72 \pm 0.31^{\mathrm{b}}$ & $2.22 \pm 0.32^{c}$ & $2.40 \pm 0.22^{\text {b.c }}$ & $2.33 \pm 0.31^{\mathrm{c}}$ \\
\hline Globulin (g/dl) & $2.80 \pm 0.13^{\mathrm{c}}$ & $3.13 \pm 0.32^{b}$ & $3.21 \pm 0.09^{\mathrm{a}}$ & $3.30 \pm 0.42^{\mathrm{a}}$ & $3.60 \pm 0.21^{\mathrm{a}}$ \\
\hline $\begin{array}{c}\text { Albumin } \backslash \text { Globulin } \\
\text { ratio }\end{array}$ & $1.43 \pm 0.43^{\mathrm{a}}$ & $0.82 \pm 0.02^{b}$ & $0.72 \pm 0.01^{\mathrm{b}}$ & $0.72 \pm 0.04^{\mathrm{b}}$ & $0.60 \pm 0.01^{b}$ \\
\hline Glucose (mg/dl) & $82.42 \pm 2.20^{\mathrm{a}}$ & $79.21 \pm 3.42^{\mathrm{a}}$ & $64.50 \pm 3.11^{b}$ & $78.11 \pm 1.13^{\mathrm{a}}$ & $61.01 \pm 2.22^{b}$ \\
\hline Calcium (mg/dl) & $7.92 \pm 0.09$ & $7.60 \pm 0.02$ & $7.52 \pm 0.04$ & $7.70 \pm 0.07$ & $7.41 \pm 0.05$ \\
\hline $\begin{array}{c}\text { Inorganic } \\
\text { phosphorus (mg/dl) }\end{array}$ & $5.41 \pm 0.42^{c}$ & $5.92 \pm 0.41^{b}$ & $6.72 \pm 0.41^{\mathrm{a}}$ & $6.10 \pm 0.92^{b}$ & $6.43 \pm 0.42^{a}$ \\
\hline \multicolumn{6}{|c|}{ Oxidative stress indicators } \\
\hline $\begin{array}{c}\text { Glutathione (GSH) } \\
\text { (mgldl) }\end{array}$ & $12.42 \pm 0.41^{\mathrm{a}}$ & $9.01 \pm 0.32^{\mathrm{a}, \mathrm{b}}$ & $6.01 \pm 0.04^{b}$ & $9.92 \pm 0.43^{\mathrm{a}, \mathrm{b}}$ & $5.01 \pm 0.01^{b}$ \\
\hline $\begin{array}{c}\text { lipid peroxidation } \\
(\mathrm{nmol} \backslash \mathrm{ml})\end{array}$ & $32.92 \pm 0.33^{b}$ & $42.11 \pm 0.11^{\mathrm{a}, \mathrm{b}}$ & $53.41 \pm 0.09^{\mathrm{a}}$ & $\underset{b}{38.91 \pm 0.01^{\mathrm{a}}}$ & $62.72 \pm 0.52^{\mathrm{a}}$ \\
\hline
\end{tabular}




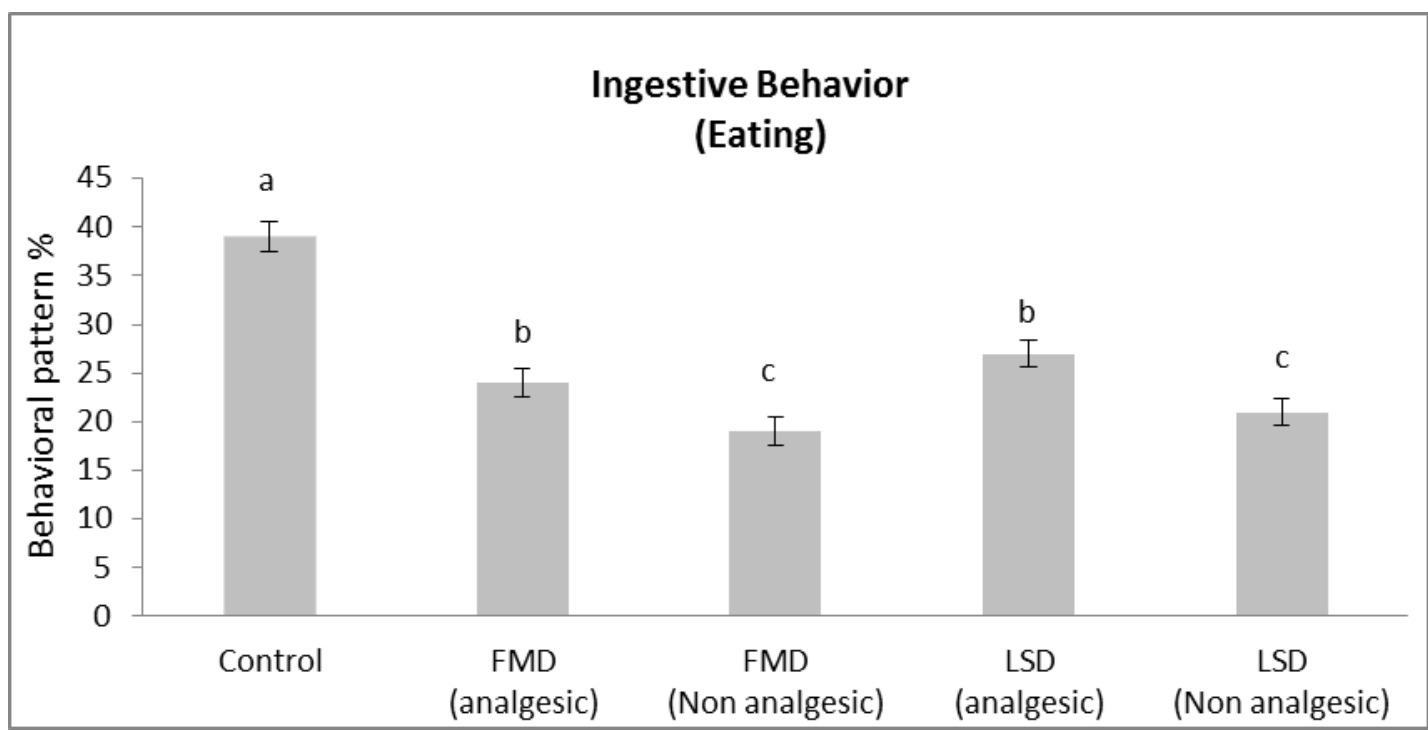

Fig. 1: Eating behavior of bull infected with FMD and LSD virus (analgesic or non-analgesic) during 60 mints daily for 5 days.

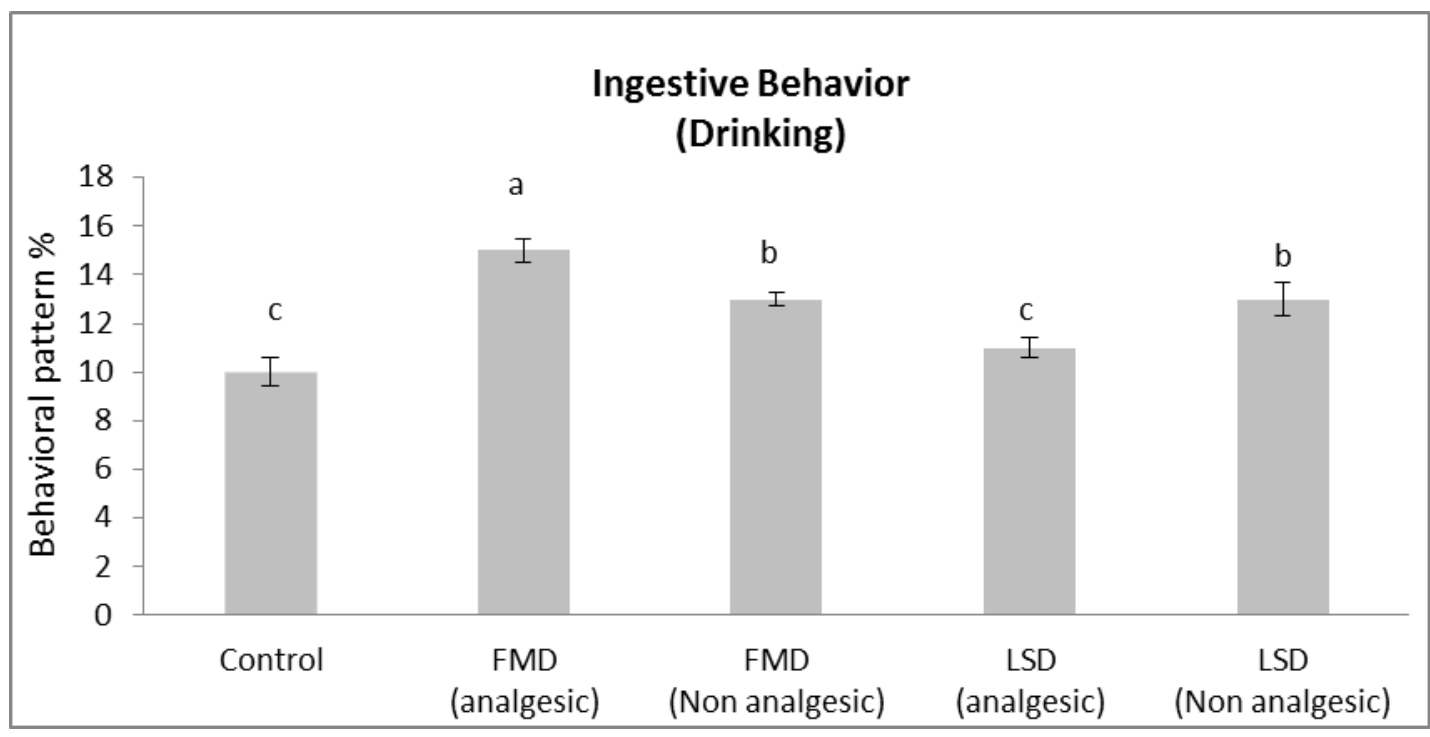

Fig. 2: Drinking behavior of bull infected with FMD and LSD virus (analgesic or non-analgesic) during 60 mints daily for 5 days. 


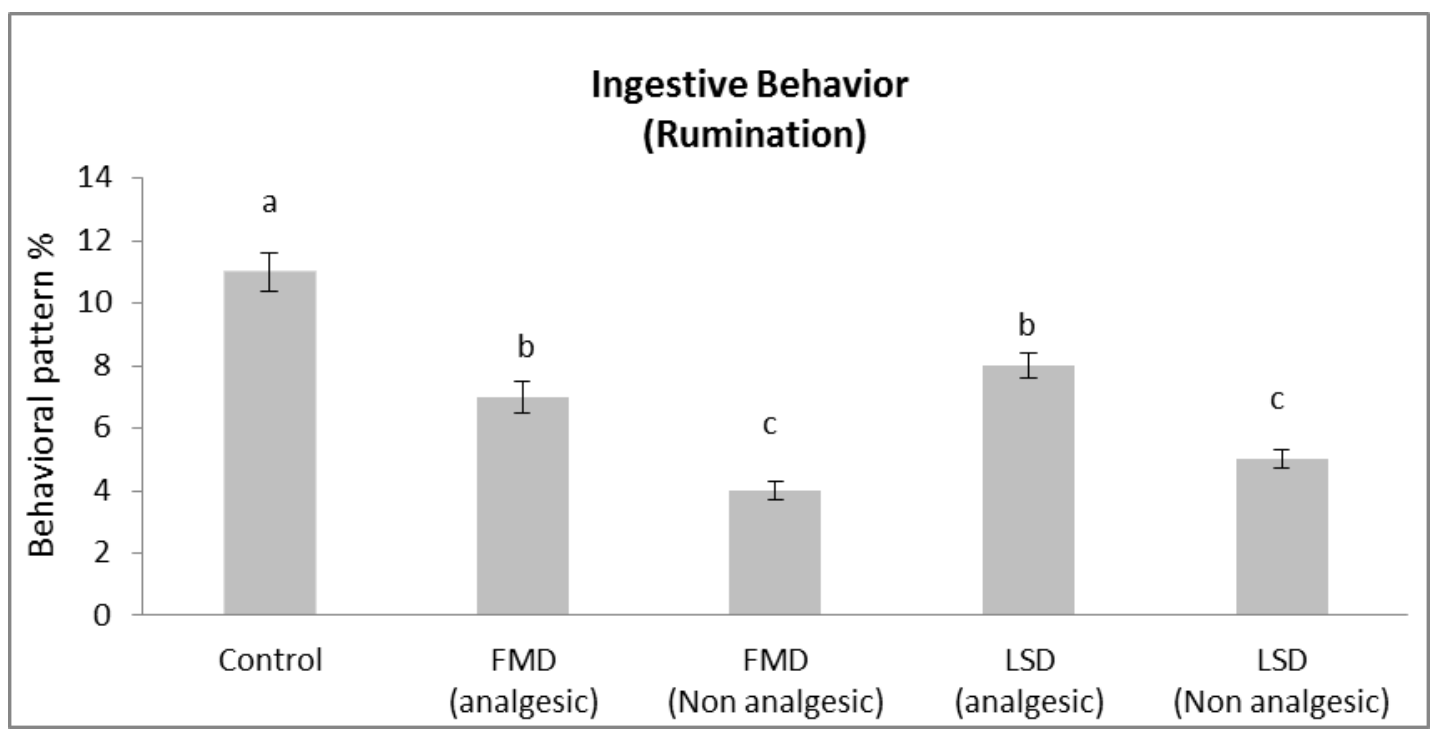

Fig. 3: Rumination behavior of bull infected with FMD and LSD virus (analgesic or non-analgesic) during 60 mints daily for 5 days.

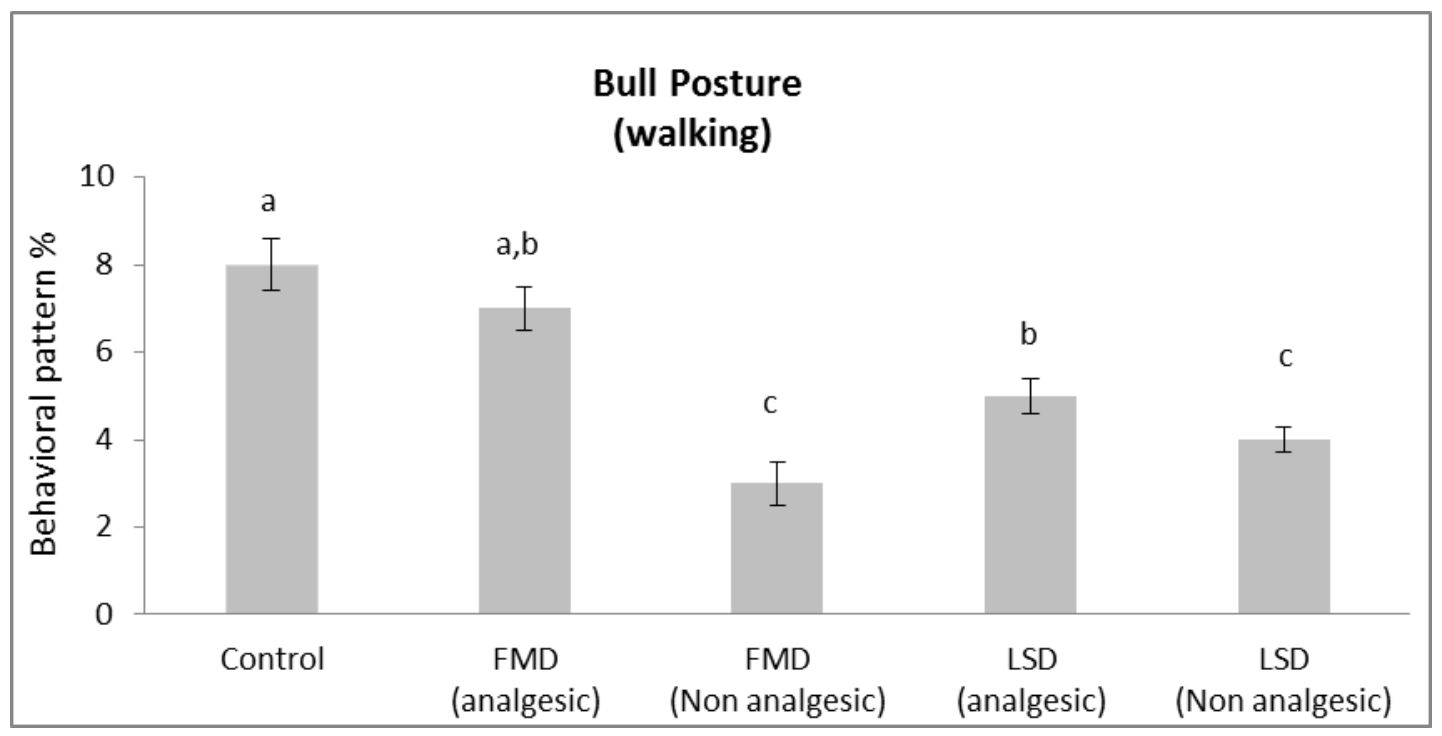

Fig. 4: Walking behavior of bull infected with FMD and LSD virus (analgesic or non-analgesic) during 60 mints daily for 5 days. 


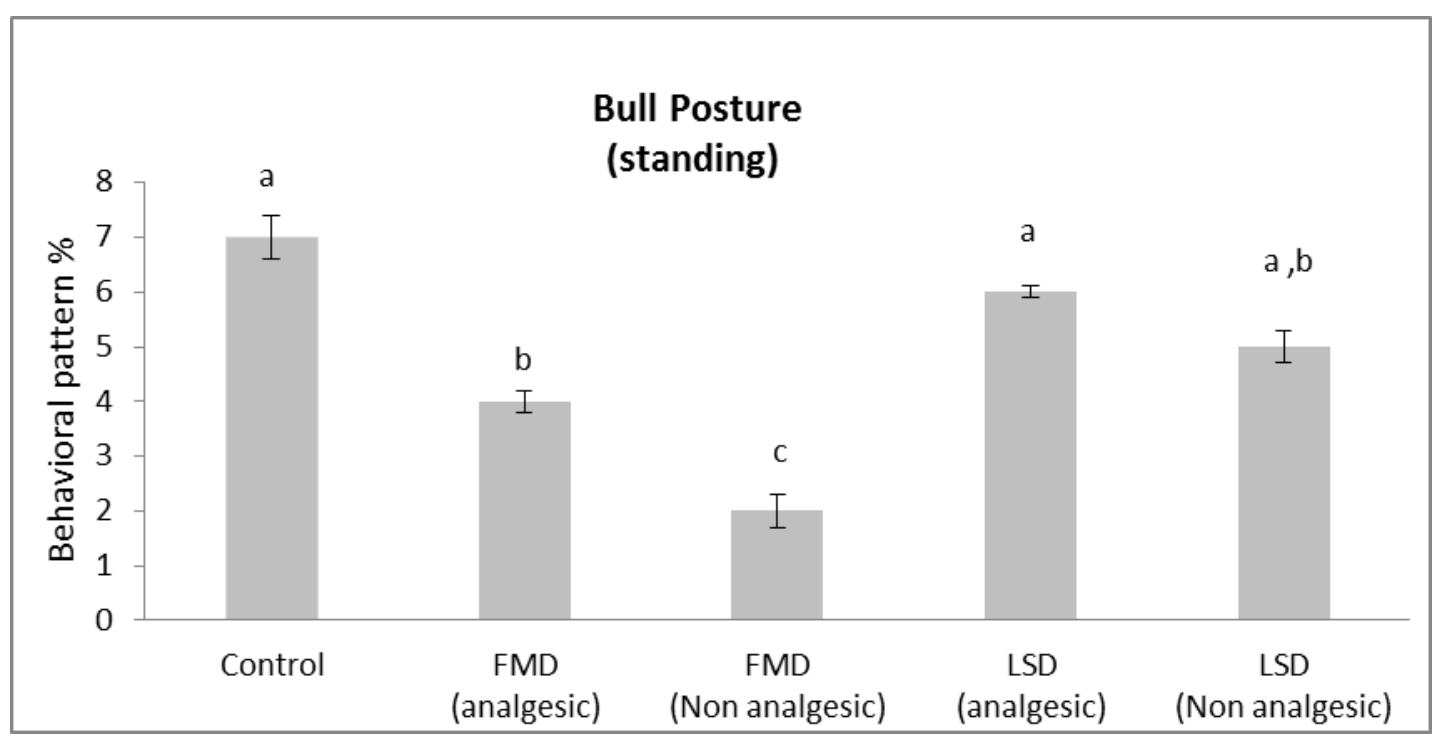

Fig. 5: Standing behavior of bull infected with FMD and LSD virus (analgesic or non-analgesic) during 60 mints daily for 5 days.

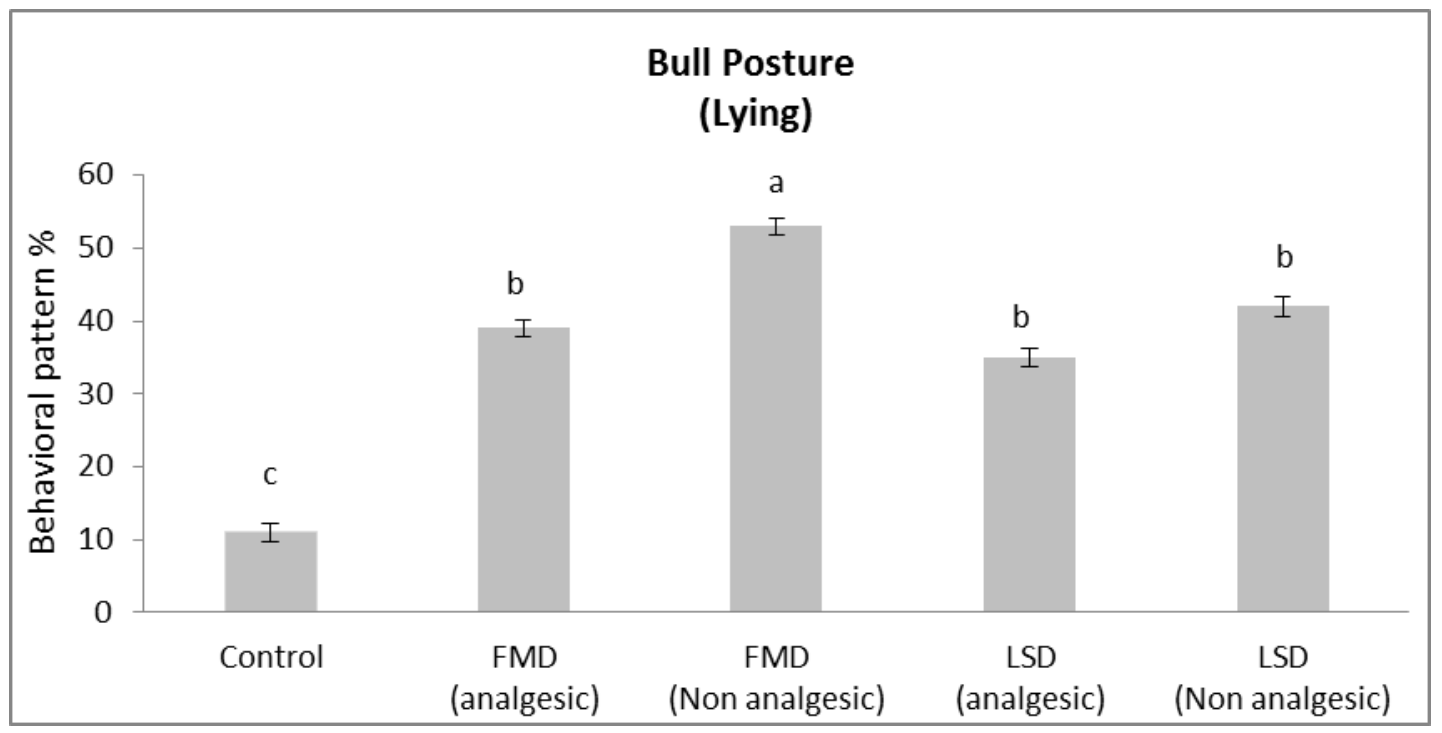

Fig. 6: Lying behavior of bull infected with FMD and LSD virus (analgesic or nonanalgesic) during 60 mints daily for 5 days. 


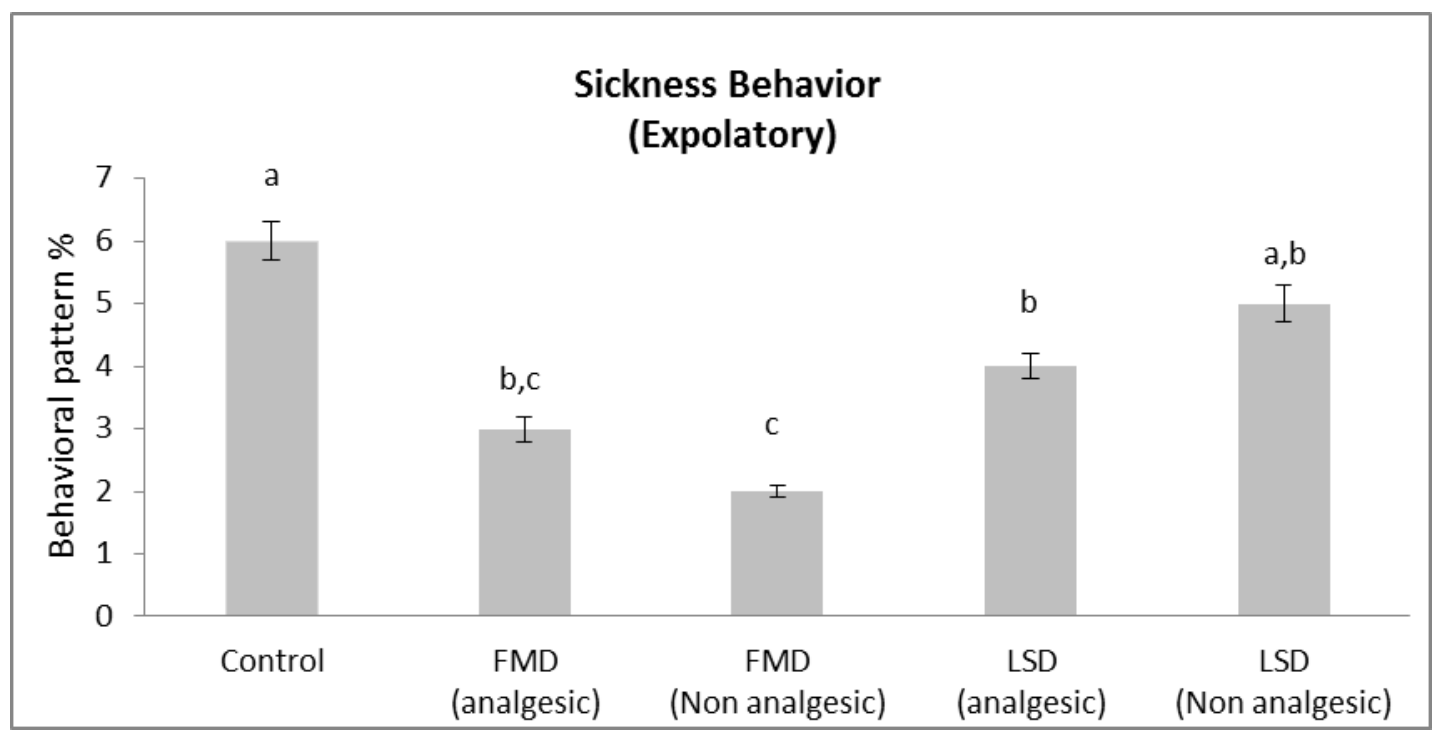

Fig. 7: Exploratory behavior of bull infected with FMD and LSD virus (analgesic or non-analgesic) during 60 mints daily for 5 days.

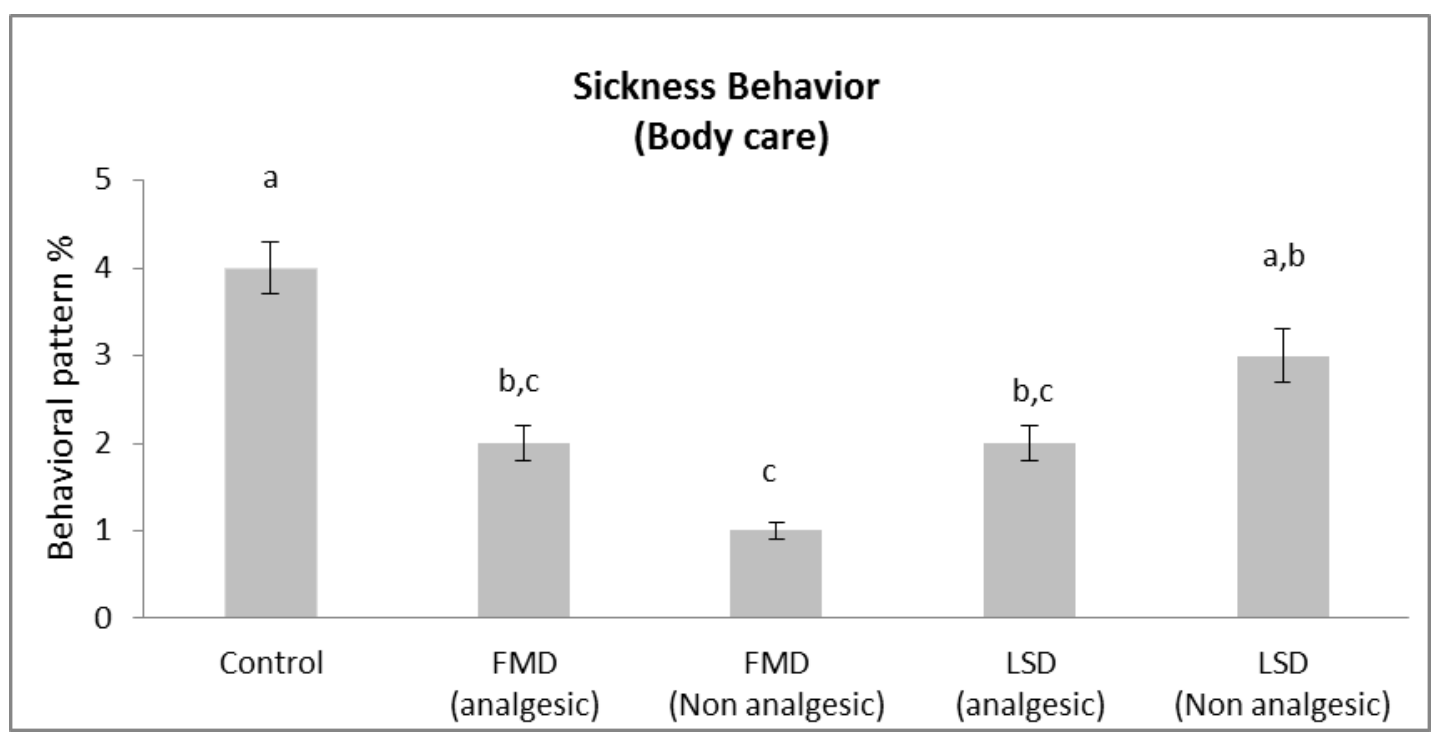

Fig. 8: Body care behavior of bull infected with FMD and LSD virus (analgesic or non-analgesic) during 60 mints daily for 5 days. 


\section{Discussion}

Pain in cattle can be objectively or subjectively measured by factors including decreased movement, decreased interaction, reduced responsiveness, postural changes and increased heart (Hudson et al., 2008) besides that, anorexia, vocalization, grinding of teeth, dull and depressed attitude, abnormal movements, abnormal posture, increased heart rate, changes in respiration, flinching, recumbent, and reduced (Watts, 2000).

\section{Physiological and appetite score}

The significant increase in temperature, respiratory and heart rate in an infected group in compared with control one this due to FMD and LSD virus accompanied by fever (Tulman et al., 2001 and Kitching et al., 2005). Many sickness behaviors support fever either by increasing, or slowing the loss of body temperature (e.g., shivering, hunched posture) or by conserving energy needed for thermogenesis (e.g., reduced activity, increased sleep lethargy, and reduced intake of food and water) (Hart, 1988 and Kelley et al., 2003). Fever, in turn, is a key response in promoting recovery (Hart, 1988). its plays multiple adaptive roles in facilitating the ability of a host to fight infection, enhancing both innate and acquired immune responses through temperature-dependent mechanisms and also via direct inhibition of bacterial proliferation by changing core body temperature above or below the pathogen's optimal temperature for growth and replication (Carlton and Demas 2015). On the other side, treated group had a significant decrease in these physiological parameters because Flunixin used as an antipyretic drug. (Teresa et al., 2014).
Finally, fever was leading to a decrease in appetite score, feeding behavior or feeding intake in animals. It may be due to changes in homeostasis of the animal body leading to reduce feed intake and this is presumably a survival strategy as digesting, especially in ruminants, and processing nutrients generate heat (i.e., thermic effect of feed.) (DeShazer et al., 2009)

\section{Ingestive behavior}

Diseases develop behavioral changes such as lethargy and in appetence along with physiologic changes and can lead to a loss in normal functioning (Weary et al., 2006) those behavioral changes can be detected by behavioral monitoring. (Bonk et al., 2013 and Ghai et al., 2015). Behavioral indicators of disease may assist with prompt identification and treatment of sick animals. (Hart, 1988).

Reduced feed intake or feeding behavior in infected animals was agreed with previous finding of (Buhman et al., 2000 ; Fogsgaard et al., 2012 and ToaffRosenstein et al., 2016) It may be due to changes in homeostasis of the animal body leading to reduce feed intake and this is presumably a survival strategy as digesting, especially in ruminants, and processing nutrients generate heat (i.e., thermic effect of feed.) (DeShazer et al., 2009) and food and water intake are reduced when there is a more severe pain (Morton and Griffiths, 1985). Moreover, this may be likely as a means of conserving energy for the febrile response and for mounting an immune response (Hart, 1988) and result from virus-host interactions extending beyond the observed acute cytopathology in virus-infected cells beside the release of cytokines, 
prostaglandins and acute phase proteins (Alexandersen et al., 2003) cytokines called interleukin-1b (IL-1b) (Dantzer 2004) decrease ghrelin hormone which involved in managing food resources and helps regulate hunger (Basa et al., 2003 and Wang et al., 2006).Beside that, leptin hormone important for sickness behaviors modulates both anorexia and lethargy (Steiner and Romanovsky, 2007) increase anorexia through increased IL-1b signaling within the hypothalamus (Ahima and Flier 2000) causing decreases food intake (Pelleymounter et al., 1995).

Rumination activity has been linked to the detection of disease (Fogsgaard et al., 2012). The significant decrease in rumination time, combined with the FMD and LSD disease, has agreement with previously described of (Fogsgaard et al., 2012 ; Miguel-Pacheco et al., 2014 and Liboreiro et al., 2015)this my related to may be associated with the common reduction in Dry matter intake (Liboreiro et al. 2015), due to pain n mouth during FMD the animals eat small practical size which decrease rumination as mentioned rumination time increases as particle size increases (Beauchemin et al., 1994) another suspect effect of fever o microphone and microflora efficacy.

\section{Sickness behavior}

Sick animals are likely to spend less time performing behaviors that are less critical for survival, including social behavior, grooming, and exploration, suggesting these may be useful indicators of developing disease. (Weary et al., 2009).

\section{Self-grooming has hygienic,} thermoregulatory, sensory stimulation, and stress-relieving effects (Spruijt et al., 1992). Our data show an decreasing in body care(grooming) was agreed with previous finding of (Fogsgaard et al., 2012;
Toaff-Rosenstein et al.,2016 and Hixson et al.,2018) this due to as part of an energyconservation strategy (Hart, 1988) also, Lethargy produced from cytokines released reduced grooming (Hart, 1988) While, differences between grooming between LSD and FMD may related to presence of skin conditions in LSD which increase oral grooming (Mooring et al., 1996) Moreover, data obtained in fig( ???) show decreasing in exploratory behavior in FMD infected animals (analgesic or not )was agreed with previous finding of (Arakawa et al., 2010; Proudfoot et al., 2014 and Hixson et al.,2018) who stated infected animal reduced social interactions this may due to pathogen-associated molecular patterns, innate immune cells to release inflammatory cytokines (Vilcoek, 1998) called interleukin-1b (IL-1b) which link the nervous, immune, and endocrine systems to modulate sickness behaviors in accordance with external factors and internal physiological (Dantzer 2004); sickness behaviors can suppress social behavior (Michael et al., 2014) which leading to reduce social exploration (Kent et al., 1992) a reduction in the time spent investigating an unfamiliar conspecific is a commonly used measure of sickness behavior (Arakawa et al., 2009) and this social withdrawal may have an evolutionary function to decrease disease transmission (Loehle, 1995), while, the non-significant difference in sickness behavior (exploration and body care) in LSD infected animals (analgesic or not ) was agreed with the finding of (Francisco and Donald, 2002) who stated that there were no differences in times receiving aggression. No differences were found in the times licking other cows; however, the frequency of times being licked was higher in the lame cows.

Despite evidence of social withdrawal in sick animals, evidence also indicates that 
social interaction is beneficial to an animal's recovery from a stressful event (Kikusui et al., 2006); for example, social contact has been shown to reduce strokerelated neurological damage in rats (Hattori et al., 2000) and group-housed calves exhibit behaviors not available to individually housed calves, including social interactions surrounding feeding, social grooming, and lying in proximity to other calves (Farevik et al., 2007 and Miller-Cushon et al., 2014). Moreover, Interactions with conspecifics, and dominance and social status can also influence the intensity of sickness behavior in a range of different contexts. In particular, these circumstances may suppress sickness at times when it is most adaptive, even if it may be damaging to short-term health. Instead of showing signs of sickness during infection, some animals may exhibit fewer and less intense sickness behaviors in a social situation because they may invest more in activities such as searching for mates or fighting for territory. (Fairbanks and Hawley, 2012).it may be a tradeoff between exhibiting sickness behaviors (reduce activity) in response to an infection and taking advantage of being in a social environment (Lopes et al. 2012). Further, animals in particular social and environmental contexts may avoid sick individuals if doing so will increase their chances of survival, or they may avoid exhibiting sickness behaviors to put themselves in a better position for territory defense, mating, or offspring survival. (Kristyn et al., 2017).

In an FMDV outbreak, transmission within and between populations can be rapid due to the short in vivo replication cycle (4-6 h) and acute onset of shedding (1-3 days) (Grau et al., 2015). The most common route of FMDV transmission is direct contact, however, transmission can occur over significant distances due to aerosol and mechanical dissemination of virus through water, feed, and fomites (Thomson et al., 2003). So that, there are managemental point in view as disease especially FMD induced or spread in the same farm let animals with other.

\section{Bull posture and pain scale}

Subjective measures such as attitude, appetite, and degree of activity are used to determine whether calves require additional examination or treatment for diseased animals (Griffin, 1996). The significant decrease in cow posture (standing and walking) and significant increase in laying behavior was agreed with previous finding of (Sylvester et al., 2004 \& Anderson and Muir, 2005) it may be due to lame cows (result from FMD or LSD) do not cope as successfully with their environment as do non-lame cows. (Francisco and Donald, 2002) it may due to heat conservation during infection is achieved through physiological (vasoconstriction) and behavioral responses (postural changes) as behavior is an important means of influencing energy expenditure; sick individuals usually increasing time at rest, likely as a means of conserving energy for the febrile response and for mounting an immune response (Hart, 1988).besides that, Lying and standing bouts are an indicator of restless behavior which is associated with pain caused by ischemia (Dinniss et al., 1999). The pain scoring scale is a useful technique it is fast and easy to use for both veterinarians and farmers which improves the consistency and help different members of staff in a practice to be able to detect pain in animal farms. (Karina, 2017). The significant increase in total pain behavior in case of FMD infected animal may 
related to the significant increase in lameness in the animals which also leading to increasing facial expression and back position as mention by (Karina, 2017). Who reported that pain in legs or abdomen may result in an arched back and lameness is a result of pain in one or several limbs. Pain in more than one limb may result in a very careful walk, rather stand a limb. The cow has a changed facial expression when in pain, a so-called pain face which may due to pain in tongue manifested by the tension of facial muscle on side of the head, Tense starel withdrawn appearance. A tension of the muscles above the eyes may be seen as "furrow lines", there is increase the tonus of the lips, straight nostrils the nostrils may be dilated and there may be lines above the nostrils which called cow facial expressions. Moreover, in cattle, a back arch is considered as an indicator of hoof lesions (Flower and Weary, 2006) and as a diagnostic indicator for abdominal pain (Radostits et al., 2007). Also, it may be due to visceral pain and viscero-visceral pain likely contributed to increased back arch (Stojkov et al., 2015). On the other side, the significant increase in total pain behavior in case of LSD infected animal may be related to the significant increase in head and ear position which due to pain will often result in a lower head carriage. This behavior may have several explanations, two of them being an overall changed posture or avoiding social interaction. (Karina, 2017) in addition to that, Lameness was also observed due to the presence of intradermal or intra-muscular LSD nodules or swellings beside joints and due to phlegmon or cellulitis. These findings agreed with that reported by (Davies 1991).

\section{Blood profile}

The decreased level of RBC in the FMD affected animals than the apparently healthy group might be due to a reduction of the process of erythropoiesis the occurrence of anemia could be attributed to endocrinopathy occurring secondary to viral infection (Gokce et al., 2004). This result was agreed with previous finding of (Ghanem and Hamid, 2010 and Barkakati et al., 2015). While, the LSD infected animals had increased erythrocyte counts, which may have been related to LSD infected animals exhibit dehydration exacerbated by fever, anorexia, and consider as chronic diseases which can be associated with absolute erythrocytosis (Morris, 2002). This result in disagreement with (Abutarbush, 2015) who finds that LSD appears to be associated with anemia. On the other side, The white blood cell (WBC) count in FMD and Lumpy skin infected animals showed a decrease as compared to apparently healthy animals this result agreed with previous work of Barkakati et al., (2015) and Neamat-Allah (2015) respectively this data may be due to the leucopenia with Eosinopenia, lymphopenia and monocytopenia, which may result from viral infections (Coles, 1986). Beside; that, LSD appears to be associated with inflammatory leukogram, anemia, thrombocytopenia these are likely due to the associated severe inflammatory process and disease complications such as anorexia and reduced muscle mass. (Abutarbush, 2015)

\section{Serum profile}

Data of different serum biochemical constituents are showed in Table (3) which showed that, there are significant decrease in total protein, albumin and albumin globulin ratio in case of analgesic and nonanalgesic affected animals (FMD or LSD) than apparently healthy animals this may be due to the anorexia which result from 
insufficient intake of protein due to lesions on the oral mucosa and interdigital regions (Gokce et al., 2004) or alterations in pancreatic cell functions developed during the clinical course of FMD (Barboni et al.,1966) also albumin levels were reduced, likely due to increased protein catabolism or decreased protein synthesis as well as hepatic damage (Hassan et al., 2011) this data in case of LSD was in agreement with (Neamat-Allah, 2015 ) and in disagreed with finding of (Shefaa et al., 2018). In case of FMD agreed with (Ghanem and Abdel-Hamid, 2010) On the other side, there are significant increase in inorganic phosphorus level in FMD and LSD affected animals than apparently healthy animals which in agreed with previous finding of (Neamat-Allah, 2015 and Shefaa et al., 2018) and (Mohapatra et al., 2005) respectively.

This result in FMD affected animals might be due to rapid respiration, higher pulse rate, tissue oxidation and acidosis due to lack of excretion (Gattani et al., 2011) also be attributed to increased salivation with the resultant dehydration and decreased renal blood flow (Gruenberg et al., 2005). Beside; that, the significant increase in Globulin level in both diseases may be is correlated with the body's immune response against infection (Agag et al., 1992). While, numerically but nonsignificant reduced in glucose levels, which may indicate decreased food intake and increased glucose catabolism in the body during LSD viral infection (Shefaa et al., 2018). This data was in disagreed with find of Barkakati et al., (2015) who find an increase.

\section{Oxidative stress indicators}

There are significant increase in lipid peroxidation (MDA) level and significant decrease in Glutathione level in case of non-analgesic affected animals (FMD or LSD) than apparently healthy animals in agreed with finding of (Shefaa et al., 2018) these may be due to free radical production and lipid peroxidation with the exhaustion of antioxidants in the blood, resulting in tissue injury (El sayed et al. 2016).

Oxidative stress increases the production of oxidants, such as MDA, that can influence the release of proinflammatory mediators, such as cytokines; these mediators play important roles in the induction of inflammation in certain skin diseases (Meffert et al., 1976). Moreover, decreases in GSH reported in LSD-infected animals withexcessive MDA production (Nashwa et al., 2017).

Role of the analgesic agent against nonanalgesic, there are a significant increase and decrease effect in Glucose and inorganic phosphorus respectively. Moreover, numerically but non-significant increase and decrease in (RBC; Total Protein; Albumin; Albumin \ Globulin ratio; Calcium and Glutathione) and (WBC and lipid peroxidation) in the analgesic affected animals compared with nonanalgesic group.

The significant increase in glucose level in analgesic agent may due to NSAIDs administration was associated with Elevation in glucose concentration (Willard et al., 1989). While, the decrease in in WBCs count may be due to a decrease of platelet by inhibits thromboxane A2, a potent stimulator of platelet aggregation (Lees et al., 2000).

\section{Conclusions}

Monitoring sickness behavior and management of pain associated with disease is a fundamental objective of veterinary medicine is to safeguard animal welfare for this reason using intravenous injection of Flunixin was a good management method for facing the negative impact of FMD and LSD virus on the maintenance, sickness behavior and cow pain scale degree which may help in 
increasing performance and production of the infected animals. Besides that, inside FMD infected same farm animal isolation was not preferable.

\section{Acknowledgements}

The authors would like to thank the members of Animal Hygiene Department, Faculty of Veterinary Medicine, and The New Valley University, Egypt for their kind help and support during the experiment.

Ethics approval and consent to participate We have got an ethical approval from hygiene Department, Faculty of veterinary medicine, The New Valley University, Egypt. Which according to the ethical rules for handling the experimental animals. All authors read and approved the final manuscript.

\section{Consent for publication}

Not applicable; Availability of data and materials. All data available in corresponding author

Funding: No funding sources.

Authors' contributions: ERD designed the experiment, performed the behavior and performance analysis, and wrote the manuscript. O.A conducted hematological analysis and wrote the manuscript. All authors reviewed and approved the manuscript.

\section{References}

Ahmed YA, Tatarczuch L, Pagel CN, Davies HM, Mirams M, Mackie EJ (2007). Physiological death of hypertrophic chondrocytes. Osteoarthritis Cartilage, 15 (5): 575-586-1239.

Abutarbush SM (2015). Hematological and serum biochemical findings in clinical cases of cattle naturally infected with lumpy skin disease. The Journal of Infection in Developing Countries, 9(03) 283288. DOI: $10.3855 /$ jidc. 5038
Agag B, Mousa S, Hassan H, Saber M, ElDeghidy N, Abdel-Aziz A (1992). Clinical, serological and biochemical studies on lumpy skin disease. Journal Applied Animal Research, 1(1):13-23.

Ahima RS and Flier JS (2000). Leptin. Annu Rev Physiol, 62:413-37. doi:10.1146/annurev.

Alexandersen S, Zhang Z, Donaldso A and Garland A (2003). The pathogenesis and diagnosis of footand- mouth disease,' J. Comp. Pathol, 129, pp. 1-36.

Al-Lethie AA, El-Hawari S F, Khaled A.S, Enas E, Arafat K, And Usama T. (2018). Evaluation of clinical recovery and healing of oral lesions by 3 different therapeutic regimens in cattle with foot and Mouth disease (FMD). Assiut Veterinary Medicine Journal, 64 (156), 89-95

Altmann JA (1974). Observational study of behavior: sampling methods. Behavior 49, 227-266.

Anderson DE and Muir WM (2005). Pain management in cattle. Vet. Clinical North Amrecian Food Animal Practical, 21, 623-635

Arakawa H, Blandino P Jr, and Deak T. (2009). Central infusion of interleukin-1 receptor antagonist blocks the reduction in social behavior produced by prior stressor exposure. Physiological Behavior. 98:139-146.

Arakawa H, Arakawa K, Deak T (2010). Sickness-related odor communication signals as determinants of social behavior in rat: A role for inflammatory processes. Hormone Behavior. 57:330-341.

Barboni E, Mannocchio I. Asdrubali G. (1966). The development of diabetes mellitus in cattle 
experimentally infected with virus of foot and mouth disease. Veterinary Italain. 17: 339.

Barkakati J, Sarma S, Kalita DJ (2015). Effect of foot and mouth disease on haematological and biochemical profile of cattle. Indian Journal Animal Reserch, 49 (5): 713-716.

Basa NR, Wang LX, Arteaga JR, Heber D, Livingston EH, Tache Y. (2003). Bacterial lipopolysaccharide shifts fasted plasma ghrelin to postprandial levels in rats. Neuroscience Letter 343:25-28.

Beauchemin KA, FarrBI, Rode LM, Schaalje GB (1994). Effects of alfalfa silage chop length and supplementary long hay on chewing and milk production of dairy cows. Journal dairy science, 77:1326-1339.

Bonk S, Burfeind O, Suthar VS, Heuwieser W (2013). Technical note: evaluation of data loggers for measuring lying behavior in dairy calves. Journal dairy science, 96:3265-3271.

Brown D C, Boston RC, Farrar JT (2013). Comparison of force plate gait analysis and owner assessment of pain using the Canine Brief Pain Inventory in dogs with osteoarthritis. Journal Veterinary International Medicine, 27: 22-30.

Buhman MJ, Perino L, Galyean M, Wittum TH, Montgomery, Swingle SR. (2000). Association between changes in eating and drinking behaviors and respiratory tract disease in newly arrived calves at a feedlot. American Journal Veterniray Reserch, 61:1163-1168.

Carlton ED, Demas GE. (2015). Body mass affects seasonal variation in sickness intensity in a seasonallybreeding rodent. Journal
Experimental Biology 218:16671676.

Coles E., (1986). Veterinary clinical pathology. Philadelphia and London: W B Saunders Company.

Dantzer RW (2004). Cytokine-induced sickness behavior: A neuroimmune response to activation of innate immunity. Euripi Journal Pharmacology. 500:399-411.

Dantzer RR, and Kelley KA (2007). Twenty years of research on cytokine-induced sickness behavior. Brain Behavior Immunology. 21:153-160.

Davies FG (1991). Lumpy skin disease, an African capri pox virus disease of cattle. Brian Veterinary Journal, 147:489-502.

DeShazer JA, Hahn GL, Xin H (2009). Basic principles of the thermal environment and livestock energetics. Pages 1-35 in Livestock Energetics and Thermal Environment Management. J.A. DeShazer, ed. ASABE, St. Joseph, MI.

Dinniss AA, Stafford K, Mellor D, Bruce R, Ward R, (1999). The behavior pattern of lambs after castration using a rubber ring and or castrating clamp with or without local anesthetic. $\mathrm{N} \mathrm{Z}$ Vet J. 47: 198-203.

Doumas BT, Biggs HG., (1972). Determination of serum globulin: standard methods of clinical chemistry. Vol. 7. Edited by Cooper. New York: Academic Press.

Duz EE, Hasan I, Neval B, Firat C, Bahtiyar B, Ersin U. (2012). Comparison of classic, Theranekron and classic-plus Theranekron treatment on the foot and mouth disease lesions in cattle 
in Van, Diyarbakir and Ankara Regions in Turkey. Journal Animal Veterinary Advanced, 11: 32583261.

El sayed HK, Mohamed HG, Abdel Hafiz NN, Rushdi M (2016). Evaluation of blood total antioxidant capacity and lipid peroxidation in cows infected with lumpy skin disease.13th Sc. cong. Hurghada: Society for Cattle Diseases.

Fairbanks B, Hawley DM. (2012). Interactions between host social behavior, physiology, and disease susceptibility: the role of dominance status and social context. In: Demas GE, Nelson R, editors. Ecoimmunology. New York (NY): Oxford University Press. p. 440.

Fajt VR, Wagner SA, Norby B (2011). Analgesic drug administration and attitudes about analgesia in cattle among bovine practitioners in the United States. Journl American Veterinary Medicine Association, 238:755-767.

Farevik G, Andersen IL, Jensen MB, Boe KE (2007). Increased group size reduces conflicts and strengthens the preference for familiar group mates after regrouping of weaned dairy calves (Bos taurus). Applied Animal Behavior Science, 108:215-228.

Feldman BF, Zinki JG, Jain VC. (2000). Schalm's veterinary hematology, 5th ed. Philadelphia: Lippincott Williams and Wilkins. Flower, F. C., and D. M. Weary., 2006. Effect of hoof pathologies on subjective assessments of dairy cow gait. Journl Dairy Scince. 89:139-146

Fogsgaard KK, Røntved CM, Sørensen P, and Herskin MS (2012). Sickness behavior in dairy cows during
Escherichia coli mastitis. Journal Dairy Science, 95:630-638.

Francisco G, Donald MB (2002). The Effects of Lameness on Social and Individual Behavior of Dairy Cows, Journal of Applied Animal Welfare Science, 5:3, 193-201,

Gattani A., Gupta KK, Joshi G. and Gupta SR (2011). Metabolic profile of foot and mouth disease stressed sheep in semi-arid region. Journal Stress Physiology Biochemistery, 7:148-153.

Ghai RR, Fugère V, Chapman CA, Goldberg TL, Davies TJ (2015). Sickness behavior associated with non-lethal infections in wild primates. Proccess Biology Scince, 282:20151436.

Ghanem MM and Hamid OM (2010). Clinical, haematological and biochemical alternations in heat intolerance (panting) syndrome in Egyptian cattle following natural foot - and- mouth disease (FMD) Tropical Animal Health Production, 42:1167-73.

Giammarco M., Fusaro I, Vignola G, Manetta AM, Gramenzi A, M. FustiniC, Palmonari $\mathrm{C}$ and Formigoni C., (2016). Effects of a single injection of Flunixin meglumine or Carprofen postpartum on haematological parameters, productive performance and fertility of dairy cattle. Animal Production Science 58(2) 322-331.

Gokce GA, Gokce V, Gunes HM. and Citil M (2004). Alterations in some haematological biochemical parameters in cattle suffering from FMD. Turkish Journal Animal Scince, 28: 723-727.

Gonzalez L, Tolkamp BJ, Coffey MP, Ferret A, Kyriazakis I (2008). 
Changes in feeding behavior as possible indicators for the automatic monitoring of health disorders in dairy cows. Journal Dairy Scince. 91:1017-1028.

Grau FR, Schroeder ME, Mulhern EL, McIntosh MT and Bounpheng MA (2015) Detection of African swine fever classical swine fever and foot-and-mouth disease viruses in swine oral fluids by multiplex reverse transcription real-time polymerase chain reaction. Journal of Veterinary Diagnostic Investigation 27, 140-149.

Griffin D. (1996) Etiology, pathogenesis and clinical signs of bovine respiratory disease. In: Bovine respiratory disease: sourcebook for the veterinary professional. Trenton, NJ: Veterinary Learning Systems, 6-11.

Gruenberg, W, Constable P, Schroder U, Staufenbiel R, Morin D and Rohn M. (2005). Phosphorus homoeostasis indairy cows with abomasal displacement or abomasal volvulus. Journal Veterinary Internal Medicine., 19: 894-894.

Hart, B. L. (1988). Biological basis of the behavior of sick animals. Neurosciences Bio behavior. Rev, 12:123-137.

Hassan H, Elkhrdosy A, Ali M. (2011). Immunobiochmical profile in cattle infected with lumpy skin disease. J Basic Chemistery, 1:21-25.

Hattori K, Lee H, Hurn PD, Crain BJ, Traystman RJ, and DeVries AC. (2000). Cognitive deficits after focal cerebral ischemia in mice. Stroke 31:1939-1944.

Heinrich AA, Duffield T, Lissemore KD, Squires EJ, Millman ST (2009). The impact of meloxicam on postsurgical stress associated with cautery dehorning. Journal of Dairy Science, 92, 540-547.

Hixson C. L., P. D. Krawczel, J. M. Caldwell,and E. K. Miller-Cushon (2018). Behavioral changes in group-housed dairy calves infected with Mannheimia haemolytica. Journal of Dairy Science 101:1-10.

Hudson C, Whay H, Huxley J. (2008). Recognition and management of pain in cattle. In Practice; 30:12634.

Johnson RW (2002). The concept of sickness behavior: a brief chronological account of four key discoveries. Veterinry Immunology Immunopathol.87, 443-450.

Kandeil A, El Shesheny R, Kayali G, Moatasim Y, Bagato O, Darwish M Gaffar A, Younes A, Farag T, Kutkat MA, Ali MA (2013). Characterization of the recent outbreak of foot-and-mouth disease virus serotype SAT2 in Egypt. Archives of virology, 158(3):619627.

Karina BG (2017). Identifying Pain Behaviors in Dairy Cattle. WCDS Advances in Dairy Technology (2017) Volume 29: 231-239.

Kelley KW, Bluthé RM, Dantzer R, Zhou $\mathrm{JH}$, Shen WH, Johnson RW, Broussard SR. Cytokineinduced sickness behavior. Brain Behavior Immunity, 17:S112-S118.

[PubMed: 12615196]

Kent S, Bluthe' RM, Dantzer R, Hardwick AJ, Kelley KW, Rothwell NJ, Vannice JL. (1992). Different receptor mechanisms mediate the pyrogenic and behavioral-effects of interleukin-1. Proc Nat Acad Science 89:9117-9120.

Kikusui T, Winslow JT, Mori Y. (2006). Social buffering: Relief from stress 
and anxiety. Philos. Trans. R. Soc. B Biol. Sci. 361:2215-2228.

Kitching RP (2002). Clinical variation in foot and mouth disease: cattle. Review Science Technology 21:499-504.

Kitching Rp, Hutber AM, Thrusfield MV (2005). A review of foot and mouth disease with special consideration for the clinical and epidemiological factors relevant to predictive modeling of the disease. The veterinary journal, 169: 197-209.

Kristyn ES and Gregory ED (2017). A Return to Wisdom: Using Sickness Behaviors to Integrate Ecological and Translational Research. Integrative and Comparative Biology, volume 57, number 6, pp. 1204-1213.

Lees P, Lendoni MF, Armstrong S, Frean SS (2000). New insight into inflammation with particular reference to the role of $\mathrm{COX}$ enzymes. 8th International Congress of the European Association for Veterinary Pharmacology and Toxicology. Jerusalem, Israel.

Liboreiro, D. N., K. S. Machado, P. R. B. Silva, M. M. Maturana, T. K. Nishimura, A. P. Brandão, M. I. Endres, and R. C. Chebel. 2015. Characterization of peripartum rumination and activity of cows diagnosed with metabolic and uterine diseases. Journal dairy science. 98:6812-6827.

Lockwood PW, Johnson JC, Katz TL (2003). Clinical efficacy of flunixin, carprofen and ketoprofen as adjuncts to the antibacterial treatment of bovine respiratory disease. Veterinary Research. 152. P. 392-394.
Loehle CT (1995). Social barriers to pathogen transmission in wild animal populations. Ecology 76:326-335.

Lomb J, Weary DM, Mills EK, von Keyserlingk MA (2017). Effects of metritis on stall use and social behavior at the lying stall. Journal Dairy Scince 101:1-9. https://doi.org/10.3168/jds.201714149.

Lopes PC, Adelman J, Wingfield JC, Bentley GE. 2012. Social context modulates sickness behavior. Behavior Ecology Sociobiology, 66:1421-8

Mattachini G, Riva E, Provolo G (2011). The lying ad standing activity indices of dairy cows in free-stall housing. Applied Animl Behavior Science, 129, 18-27.

May SA, Lees P. (1996). Nonsteroidal anti-inflammatory drugs. In McIlwraith CW, Trotter GW, eds. Joint disease in the horse. Philadelphia: WB Saunders,223237.

Mcilwraith CW, Frisbie DD, Kawcak CE. (2001). Nonsteroidal AntiInflammatory Drugs. Proc. AAEP (47): 182-187.

Meffert H, Diezel W, Sonnichsen N. (1976). Stable lipid peroxidation products in human skin: detection, ultraviolet light-induced increase, pathogenic importance. Experiential. 32:1397-1398.

Miguel-Pacheco G, Kaler J, Remnant L, French AP, Pridmore TP, Huxley JN (2014). Behavioral changes in dairy cows with lameness in an automatic milking system. Applied Animal Behavior Science, 150:1-8

Miller-Cushon EK, Bergeron R, Leslie KE, Mason GJ, and DeVries TG (2014). Competition during the milk- 
feeding stage influences the development of feeding behavior of pair-housed dairy calves. Journal Dairy Scince, 97:6450-6462.

Millman TS (2013). Behavioral Responses of Cattle to Pain and Implications for Diagnosis, Management, and Animal Welfare. Veterinary Clinical Food Animal, 29 47-58.

Mohapatra AK, Kundu A, Bisoi PC and Prusty BM (2005). Haematological and biochemical changes in crossbred cattle affected with Foot and Mouth disease. Indian Veterinary Journal, 82: 141-144.

Molgaard, L., B. M. Damgaard, V. BjerreHarpoth, and M. S. Herskin. (2012). Effects of percutaneous needle liver biopsy on dairy cow behavior. Research Veterinary Scince. 93:1248-1254.

Mooring, M. S., A. A. McKenzie, and B. L. Hart. 1996. Grooming in impala: Role of oral grooming in removal of ticks and effects of ticks in increasing grooming rate. Physiol. Behav. 59:965-971. doi:10.1016/0031-9384(95)02186-8

Morris DD. (2002). Alterations in the erythron. In: Smith BP, editor. Large animal internal medicine. 2nd ed. New York: Mosby; p. 415419.

Morton, DB, Griffiths, PHM (1985). Guidelines on the recognition of pain, distress and discomfort in experimental animals and a hypothesis for assessment. Veterinary Record, 116, 431-436.

Nashwa MH, Ahmed AS, Mohamed ZY. (2017). Molecular, clinicopathological and sero-diagnosis of LSDV in cattle at sharkia and fayoum governorates. J Virol Sci. $1: 1-11$.
Neamat-Allah

ANF

(2015)

Immunological, hematological, biochemical, and histopathological studies on cows naturally infected with lumpy skin disease. Vet World 8: 1131-1136.

Neamat-Allah

ANF.

(2015). Immunological, hematological, biochemical, and histopathological studies on cows naturally infected with lumpy skin disease. Vet World. 8(9):1131-1136.

Ohkhawa H, Ohsini N, Yagi K. (1979). Assay for lipid peroxides in animal tissues by thiobarbituric acid reaction. Anal Biochemistry. 95:351-358.

Owens C, Belcher R. (1965). Clometeric method for the determined glutathione. Biochemistry Journal 94(3):705-711.

Pelleymounter MA, Cullen MJ, Baker MB, Hecht R, Winters D, Boone T, Collins F. (1995). Effects of the obese gene-product on body-weight regulation in ob/ob mice. Science 269:540-3.

Proudfoot, K. L., M. B. Jensen, D. M. Weary, and M. A. G. von Keyserlingk. (2014). Dairy cows seek isolation at calving and when ill. J.Dairy Sci. 97:2731-2739.

Radostitis, O.M.; Gay, C.C.; Hinchcliff, K.W. and Constable, P.D. (2007): Veterinary medicine. A text book of the diseases of cattle, horses, sheep, pigs and goats. 10th Ed., Saunders Elsevier. pp: 3-31.

Radostits, O. M., C. C. Gay, K. W. Hinchcliff, and P. D. Constable. (2007). Veterinary Medicine: A Textbook of the Diseases of Cattle,Horses, Sheep, Pigs and Goats. 10th ed. Saunders, Philadelphia, PA. 
Rushen, J., de Passillé, A.M., von Keyserlingk, M.A.G., Weary, D.M. (2008). The Welfare of Cattle. Springer. Dordrecht, The Netherlands.

Rutherford, K.M.D., 2002. Assessing pain in animals. Ani. Welfare. 11, 3153.

Salib F. Awadalla and Osman A. Hassan (2011). Incidence of lumpy skin disease among Egyptian cattle in Giza Governorate, Egypt. Veterinary World, Vol.4(4):162167.

Sepulveda-Varas, P., D. M. Weary, and M. A. G. von Keyserlingk. (2014). Lying behavior and postpartum health status in grazing dairy cows. Journal Dairy Scince 97:63346343.

Shahan M (1962) Shahan: Virus of Footand-Mouth Disease. Ann N Y Acad Sci 101:444-454

Shefaa A. M. El-Mandrawy \& Rasha T. M. Alam (2018) Hematological, biochemical and oxidative stress studies of lumpy skin disease virus infection in cattle, Journal of Applied Animal Research, 46:1, 1073-1077.

Spruijt, B. M., R. A. M. van Hooff, and W. H. Gispen. 1992. Ethology and neurobiology of grooming behavior. Physiol. Rev. 72:825852.

SPSS., (2001). SPSS user's guide statistics Version 10. Copyright SPSS Inc., USA.

Stamp-Dawkins, M., (2007). Observing Animal Behavior: Design and Analysis of Quantitative Data. Oxford University Press, Oxford.

Steiner AA, Romanovsky AA. 2007. Leptin: At the crossroads of energy balance and systemic inflammation. Prog Lipid Res 46:89-107.
Stenfeldt C, Pacheco JM, Smoliga GR, Bishop E, Pauszek SJ, Hartwig EJ, Rodriguez LL and Arzt J (2016) Detection of foot-and-mouth disease virus RNA and capsid protein in lymphoid tissues of convalescent pigs does not indicate existence of a carrier state. Transboundary and Emerging Diseases 63, 152-164.

Stewart, M., Verkerk, G.A., Stafford, K.J., Schaefer, A.L., \& Webster, J.R. (2010) Noninvasive assessment of autonomic activity for evaluation of pain in calves using surgical castration as a model. Journal of Dairy Science, 93, 3602-3609.

Stojkov, J., M. A. G. von Keyserlingk, J. N. Marchant-Forde, and D. M. Weary. (2015). Assessment of visceral pain associated with metritis in dairy cows. J. Dairy Sci. https:// doi .org/ $10.3168 /$ jds .2014 $-9296$.

Sylvester SP, Stafford KL, Mellor DJ, Bruce RA, Ward RN (2004). Behavioral responses of calves to amputation dehorning with and without local anaesthetic. Australian Veterinary Journal, 82, 697-700.

Teresa LL, Lisa AL, Lindsey WK, Geoffrey WS, David JS, Sarah AW, Weilin LS, Huali WE, Jim ER (2014) Development of a physiologically based pharmacokinetic model for flunixin in cattle (Bos taurus). Food Additives \& Contaminants: Part A, 2014. Vol. 31, No. 9, 1506-1521.

Thomsen, P. T., I. Anneberg, and M. Herskin. (2012). Differences in attitudes of farmers and veterinarians towards pain in dairy cows. Veterinary Journals, 194:9497. 
Thomson GR, Vosloo W and Bastos ADS (2003). Foot and mouth disease in wildlife. Virus Research 91, 145161.

Toaff-Rosenstein R, Gershwin AJ, Zanella, Tucker CB (2016). The sickness response in steers with induced bovine respiratory disease before and after treatment with a nonsteroidal anti-inflammatory drug. Applied Animal Behavior Scince. 181:49-62.

Tulman ER, Afonso M, Lu Z, Zsak L, Kutish GF, Rock DL (2001). Genome of Lumpy Skin Disease Virus. Journal of virology, 75(15): 7122-7130.

USFDA. (2004). Freedom of Information Summary, Supplemental New Animal Drug Application for Banamine Injectable Solution (Flunixin meglumine) NADA 101479 [Internet].[cited 2014 Jul 17]. Available from: Products/FOIADrugSummaries/uc m064910.pdf

http://www.fda.gov/downloads/Ani malVeterinary/Products/Approved AnimalDrug

Vilcoek J. (1998). The Cytokines: an overview. In: Thomson A, editor. The cytokine handbook. 3rd Edition. San Diego,CA: Academic Press

Wagner SA, Young M, Tena J, Manning BH (2016). Short communication: Behavioral evaluation of the analgesic effect of flunixin meglumine in lame dairy cows. Journal dairy Scince, 100:1-5.

Wang LX, Basa NR, Shaikh A, Luckey A, Heber D, St-Pierre DH, Tache Y. (2006). LPS inhibits fasted plasma ghrelin levels in rats: role of IL-1 and PGs and functional implications. American Journals
Physiol-Gastrointest Liver Physiology 291: G611-20.

Watts SA (2000). A survey of bovine practitioners' attitudes to pain and analgesia in cattle. Cattle Practice, 8:361-362.

Weary DM, Huzzey JM, von Keyserlingk MAG. (2009). Board-invited review: using behavior to predict and identify ill health in animals. Journal Animal Science ,87:770777.

Weary DM, Niel L, Flower FC, Fraser D (2006). Identifying and preventing pain in animals. Applied Animal Behavior Scince, 100, 64-76.

Willard MD, Tvedten H, Turnwald G.H. (1989). Small Animal Clinical Diagnosis by Laboratory Methods. W.B. Saunders Company, Philadelphia, USA., pp. 90-91; 108-114; 162; 217-219; 362-363. 